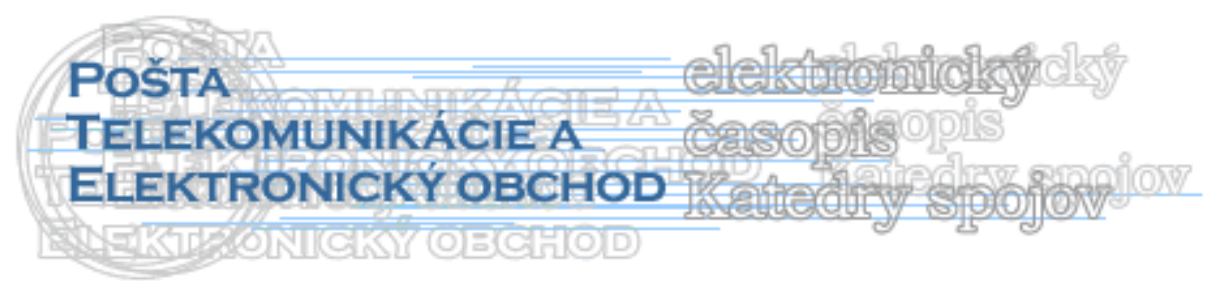

\title{
K PROBLEMATIKE STANOVENIA POČTU ZAMESTNANCOV
}

\author{
Pavel Kaštánek* Anna Pad'ourová $^{+}$
}

Vzhl'adom k skutočnosti, že náklady na pracovnú silu predstavujú v podnikovom transformačnom procese významnú položku ovplyvňujúcu úroveň hospodárenia a ekonomiky podniku je bezpodmienečne nevyhnutné okrem iného venovat' pozornost' stanoveniu adekvátneho a primeraného počtu zamestnancov, či vo vzt’ahu k rozsahu a kvalite ostatných výrobných faktorov, resp. v súvzt’ažnosti medzi ich diferencovanými kategóriami, pracovnými činnost’ami a funkciami.

Jednou z možností riešenia tohto problému vo vel'kých podnikoch (s viacerými vnútropodnikovými organizačnými jednotkami) ako je napr. Slovenská pošta, a.s., Slovak Telekom, a.s. je uplatnenie metódy porovnávania výkonov a metódy viacnásobných variačných rozpätí.

Podstata metódy porovnávania výkonov spočíva $\mathrm{v}$ porovnávaní spotreby práce na vykonanie vybraných činností $\mathrm{v}$ skupine vybraných organizačných jednotiek na základe pomerových hodnôt daných pomerom počtu zamestnancov vykonávajúcich túto činnost' a hodnoty charakteristického "faktora vplyvu". Ako faktory vplyvu sa vyberajú tie merné hodnoty resp. ukazovatele, ktoré sú $\mathrm{k}$ dispozícii $\mathrm{z}$ jestvujúcich podkladov a ktoré majú rozhodujúci vplyv na spotrebu práce skúmanej činnosti.

Metodický postup metódy sa realizuje v nasledovných krokoch:

a) vypracovanie zoznamu činností, ktoré budú normované,

b) zostavenie zoznamu faktorov ovplyvňujúcich spotrebu práce týchto činností,

c) zber potrebných informácií,

d) výpočet smerného (progresívneho) počtu zamestnancov pre skúmané činnosti $\mathrm{v}$ jednotlivých organizačných jednotkách,

e) analytické porovnávanie výkonov.

Metodický postup prvých troch krokov je zrejmý a nebudem ho detailnejšie popisovat'. V štvrtom kroku sa štatisticky spracuje súbor informácií pre normovanú činnost' tak, že sa stanoví aritmetický priemer vplyvu príslušného faktora na počet zamestnancov, ktorý je základom d’alšieho výpočtu.

Pomerový koeficient sa stanoví nasledovne:

\footnotetext{
*Ing. Pavel Kaštánek, Katedra spojov, Fakulta prevádzky a ekonomiky dopravy a spojov, Žilinská univerzita v Žiline, Univerzitná 1, 01026 Žilina, Slovenská republika, tel.: +421415133122, fax: +421415655615

e-mail: Pavel.Kastanek@ffpedas.utc.sk

+ Ing. Anna Pad'ourová, Katedra spojov, Fakulta prevádzky a ekonomiky dopravy a spojov, Žilinská univerzita v Žiline, Univerzitná 1, 01026 Žilina, Slovenská republika, tel.: +421415133129 , fax: +421415655615

e-mail: Anna.Padourova@fpedas.utc.sk
} 


$$
H_{i}=\frac{P_{i}}{F v_{i}}, \mathrm{kde}
$$

$H_{i}$ je pomerový koeficient, t.j. hodnota skúmaného pomeru skutočného počtu zamestnancov a hodnoty faktora vplyvu,

$P_{i}$ - počet zamestnancov, t.j. skutočný počet zamestnancov v skúmanej činnosti i-tej organizačnej jednotky,

$F v_{i}$ - faktor vplyvu, t.j. hodnota činitel'a s rozhodujúcim vplyvom na počet zamestnancov v skúmanej činnosti i-tej organizačnej jednotky.

Nasleduje výpočet strednej, optimálnej, alebo progresívnej hodnoty pomerových koeficientov v závislosti od úmyslu a potreby stanovit' počet zamestnancov ako optimálny, resp. progresívny. Rozdiel medzi optimálnym a progresívnym počtom je potom rozdielom $\mathrm{v}$ miere uvažovanej “tvrdosti“" prípadného zníženia počtu zamestnancom.

$$
H s t r=\frac{\sum_{i=1}^{n} H_{i}-H m n-H m x}{n-2}, \mathrm{kde}
$$

Hstr je stredná hodnota z vypočítaných pomerových koeficientov, Hmn - minimálna hodnota z vypočítaných pomerových koeficientov, $H m x$ - maximálna hodnota $\mathrm{z}$ vypočítaných pomerových koeficientov, $n$ - počet organizačných jednotiek,

$$
H o p t=\frac{H m n+H s t r}{2}, \mathrm{kde}
$$

Hopt je optimálna hodnota pomerového koeficientu,

$$
H p r o g=\frac{H o p t+H m n}{2}, \mathrm{kde}
$$

Hprog je progresívna hodnota pomerového koeficientu,

$$
\text { Popt }_{i}=H_{o p t} * F v_{i}, \mathrm{kde}
$$

Popt $_{i}$ je optimálna hodnota počtu zamestnancov pre skúmanú činnost' v i-tej organizačnej jednotke,

$$
\text { Pprog }=H_{p r o g}^{*} F v_{i}, \text { kde }
$$

$P_{\text {prog }}$ je progresívna hodnota počtu zamestnancov pre skúmanú činnost' $\mathrm{v}$ i tej organizačnej jednotke.

Ak je potrebné pracovat's viacnásobnou závislost’ou t.j. s vplyvom viac než jedného faktora, všetky hodnoty $\mathrm{F}$ je potrebné otestovat' váhami faktorov. 
Ak sa vykonáva "váženie" vel'kostí faktorov vplyvu potom sa pomerový koeficient vypočíta podl'a vzt'ahu:

$$
H_{i}=P_{i} * \sum_{j=1}^{m} \frac{W_{j}}{F v_{i j}}, \text { pričom platí } \sum_{j=1}^{m} W_{j}=1, \text { kde }
$$

$W_{j}$ je váha j-tého faktora,

$m$ - počet faktorov.

Analogicky ako v prípade bez váh sa stanoví stredná, optimálna a progresívna hodnota pomerového koeficientu. Optimálny resp. progresívny počet zamestnancov v skúmanej činnosti v i-tej organizačnej jednotke sa potom vypočíta podl'a vzt'ahov:

$$
\text { Popt }_{i}=\frac{\text { Hopt }}{\sum_{j=1}^{m} \frac{W_{j}}{F v_{i j}}} \quad \text { resp. } \quad \text { Pprog }_{i}=\frac{\text { Hprog }}{\sum_{j=1}^{m} \frac{W_{j}}{F v_{i j}}}
$$

Stanovenie počtu zamestnancov skúmanej pracovnej činnosti použitím jedného faktora vplyvu môže spôsobit', že dosiahnuté výsledky budú zat'ažené určitou chybou, vyplývajúcou z nepoznania značného percenta vplyvov. Tento prístup je možné aplikovat' v prípade, kedy na skúmanú činnost' jednoznačné vplýva jeden faktor vplyvu, alebo ked' jeden faktor v porovnaní s ostatnými má rozhodujúci vplyv v prípade jeho váženia /napr. $\mathrm{W}=0.8$ $0.95 /$.

Použitie viacerých faktorov vplyvu by malo umožnit' objektívnejšie a presnejšie určit' počet zamestnancov skúmanej činnosti. Presnost' výsledkov je však v značnej miere závislá od správneho výberu faktorov vplyvu a určenia "váhy" ich vplyvu na celkový objem prác v skúmanej činnosti.

Porovnaním počtu zamestnancov v skúmanom útvare získame prehl'ad o rozdiele $\mathrm{v}$ spotrebe práce $\mathrm{v}$ jednotlivých organizačných jednotkách, a tým aj bez hlbšej analýzy určíme tie, $v$ ktorých bude nevyhnutné prijat' racionalizačné opatrenia.

Metóda viacnásobných variačných rozpätí je d’alšou z možných progresívnych metód na výpočet počtu zamestnancov. Vychádza $\mathrm{z}$ predpokladu, že pri medzizávodovom porovnávaní personálneho obsadenia skúmanej činnosti platí, že:

a) medzi počtom zamestnancov potrebným $\mathrm{k}$ zabezpečeniu určitej činnosti a faktorom ovplyvňujúcim túto spotrebu pôsobia proporcionálne vzt'ahy, ktoré možno vyjadrit' ako vzt'ahy lineárne,

b) organizačná jednotka - reprezentant podniku - plniaci dobre úlohy v skúmanej činnosti a s relatívne malým počtom zamestnancov, môže slúžit' ako vzor pre zistenie závislosti medzi počtom zamestnancov skúmanej činnosti a ovplyvňujúcim faktorom.

Navrhovaný počet zamestnancov môže byt' formulovaný ako prepočítaný, alebo smerný.

\section{A. Výpočet prepočítaného počtu zamestnancov:}

1) Určíme "vzorovú organizačnú jednotku“- reprezentant podniku, ktorá kvalitne plní stanovené úlohy $\mathrm{v}$ skúmanej činnosti $\mathrm{s}$ relatívne najmenším počtom 
zamestnancom. Pôjde teda o organizačnú jednotku s najmenším pomerovým koeficientom, pričom pomerový koeficient vypočítame podl'a vzt’ahu:

$$
p k_{i}=\frac{P \dot{u}_{i}}{P_{i}}, \mathrm{kde}
$$

$p k_{i}$ je pomerový koeficient $\mathrm{v}$ i-tej organizačnej jednotke,

$P u_{i}$ - počet zamestnancov útvaru $\mathrm{v}$ skúmanej činnosti $\mathrm{v}$ i tej organizačnej jednotke,

$P_{i}$ - celkový počet zamestnancov vo fyzických osobách v príslušnej organizačnej jednotke.

2) Prepočítaný počet zamestnancov môžeme potom vypočítat' nasledovne:

$$
\operatorname{Pprep}_{i}=p k_{\min } * P_{i}, \mathrm{kde}
$$

Pprep $_{i}$ je prepočítaný počet zamestnancov skúmanej činnosti i- tej organizačnej jednotky,

$p k_{\text {min }}$ - najnižšia hodnota pomerového koeficientu (t.j. vo "vzorovej organizačnej jednotke").

Vzhl'adom $\mathrm{k}$ tomu, že takto vypočítaný počet zamestnancov činnosti je odvodený len od minimálnej hodnoty pomerového koeficientu, vypočítané hodnoty $\mathrm{v}$ relatívne nižšej miere zohl'adňujú aj prípadné d’alšie nešpecifikované faktory ovplyvňujúce počet zamestnancov. Tento nedostatok do určitej miery odstraňuje ukazovatel' smerného počtu zamestnancov.

\section{B. Výpočet smerného počtu zamestnancov:}

Pre výpočet je potrebné stanovit' ukazovatel' priemernej potreby zamestnancov pripadajúci na jedného pracovníka skúmaného útvaru a to takto:

$$
u=\frac{\sum_{i=1}^{n} p k_{i}-p k_{\min }-p k_{\max }}{n-2}, \mathrm{kde}
$$

$u$ je ukazovatel' priemernej potreby zamestnancov pripadajúci na jedného pracovníka sledovanej činnosti,

$n$ - počet organizačných jednotiek v súbore,

$p k_{\min }, p k_{\max }$ - minimálna a maximálna hodnota pomerového koeficientu.

Ukazovatel' smerného počtu zamestnancov $S p_{i}$ sledovanej činnosti v i-tej organizačnej jednotke vypočítame podl'a vzt'ahu:

$$
S p_{i}=u s^{*} P_{i} \quad \text { pričom } \quad u s=\frac{u+p k_{\min }}{2}, \mathrm{kde}
$$


us je ukazovatel' priemernej smernej potreby zamestnancov pripadajúci na jedného zamestnanca sledovanej činnosti.

Hodnotu smerného počtu vypočítanú metódou viacnásobných normovaných variačných rozpätí vypočítame podl'a vzt’ahu:

$$
P S v_{i}=\frac{\frac{P_{i}}{n} * \sum_{i=1}^{n} S p_{i}}{\frac{1}{n} * \sum_{i=1}^{n} P_{i}}=\frac{P_{i} * \sum_{i=1}^{n} S p_{i}}{\sum_{i=1}^{n} P_{i}}
$$

\section{Literatúra:}

[1] KAŠTÁNEK, P.- ROVŇANOVÁ, T.- ŠTOFKOVÁ, J.: Ekonomika spojového podniku I, VŠDS Žilina 1994

\section{Resumé}

V predloženom článku vzhl'adom na permanentnú aktuálnost' problému hl'adania zdrojov znižovania nákladov a výdajov $\mathrm{v}$ podnikovom transformačnom procese sú predstavené potenciálne možné spôsoby znižovania (optimalizácie) počtu niektorých kategórií zamestnancov to prostredníctvom metód porovnávania výkonov a viacnásobných variačných rozpätí. 